\title{
Penerapan Pembelajaran Berkarakter Islami Pada Program PPL Mahasiswa Pendidikan Matematika Unissula Semarang
}

\author{
Imam Kusmaryono $^{1}$, Hevy Risqi Maharani2 \\ 1,2 Mathematics Education Departement, Universitas Islam Sultan Agung Semarang \\ e-mail: kusmaryono@unissula.ac.id
}

\begin{abstract}
ABSTRAK. Tujuan penelitian adalah untuk mengetahui tingkat keefektifan dari penerapan pembelajaran berkarakter Islami dalam pelaksanaan PPL, sebagai bekal kompetensi calon guru pada mahasiswa pendidikan matematika Universitas Islam Sultan Agung (Unissula) Semarang. Penelitian ini menggunakan metode penelitian kombinasi kuantitatif dan kualitatif dengan pendekatan concurrent embedded dimana metode kuantitatif sebagai metode primer. Hasil penelitian menunjukkan tingkat keefektifan terpenuhi oleh unsur: (1) Kompetensi pedagogik dan profesional mahasiswa pendidikan matematika dalam program PPL di sekolah mitra mencapai kategori baik yaitu rata-rata skor 78,39, (2) Terdapat pengaruh aktivitas pembelajaran mahasiswa PPL dan minat siswa terhadap hasil belajar matematika siswa dalam pembelajaran berkarakter Islami dengan persamaan regresi ganda $\hat{Y}=$ $36,907+0,200 X_{1}+0,634 X_{2}$, yang bersifat linier. Besarnya kontribusi aktivitas dan minat siswa terhadap hasil belajar ditunjukkan dari nilai $R$ square (indeks determinasi) sebesar 0,416 atau 41,6\%, artinya aktivitas mahasiswa PPL dan minat siswa mempengaruhi hasil belajar sebesar 41,6\%, sedangkan sebesar 58,4\% dipengaruhi oleh ada variabel lain, dan (3) Hasil belajar matematika siswa melalui pembelajaran berkarakter Islami mencapai 76,52 yang berarti lebih baik daripada hasil belajar siswa dalam pembelajaran matematika tidak berkarakter Islami hanya mencapai 70,29. Aktivitas pelaksanaan pembelajaran matematika berkarakter Islami yang dilaksanakan mahasiswa PPL sudah memenuhi standard yang ditetapkan oleh program studi. Sedangkan minat siswa terhadap pembelajaran matematika berkarakter Islami juga tinggi.
\end{abstract}

Kata kunci: penerapan; pembelajaran matematika; berkarakter Islami .

\section{PENDAHULUAN}

Pendidikan haruslah merupakan usaha membangun generasi yang lebih baik sebagai khalifah Allah di bumi, untuk membangun masa depan kehidupan yang lebih baik bagi bangsa maupun dunia seluruhnya. Generasi yang baik terdiri dari individu-individu yang baik. Dalam kriteria AlQur'an, sebaik-baik manusia adalah manusia bertakwa, berbudi mulia dan berilmu tinggi. Hadits Rasulullah SAW juga menyatakan "sebaik-baik manusia adalah yang paling bermanfaat bagi manusia." Mereka itulah yang berpotensi menjadi generasi terbaik yang dijanjikan oleh Allah SWT bakal sanggup memimpin dunia dengan kerahmatan atau penuh kasih sayang. Generasi terbaik sebagaimana Allah firmankan dalam Al-Qur'an (QS: Ali Imron, 110) adalah generasi khaira ummah. Ciri dan faktor penentu (defining factor) mereka adalah kualitasnya: (1) beramar ma'ruf dan nabi munkar, dan (2) senantiasa mengajak manusia untuk beriman. Mereka adalah generasi yang sangat mencintai Allah dan menyayangi sesama, dan senantiasa berbuat untuk selamat menyelamatkan.

Pembelajaran tidak semata-mata merupakan kewajiban pendidik dalam menghabiskan cakupan materi dalam rentang waktu yang ditentukan. Tetapi merupakan proses yang penuh aktivitas produktif yang dilakukan pendidik dan peserta didik. Karenanya pembelajaran merupakan proses aktif. Pertanyaannya adalah, "apakah proses aktif yang dimaksud sudah dilakukan oleh 
pendidik, bagaimana pendidik mendesain pembelajarannya dengan berkarakter islami, sehingga mampu menciptakan kelas yang dinamis, dan mampu meletakkan dasar-dasar akblaqul karimah pada diri siswa" menuju terwujudnya generasi terbaik (khairu ummah).

Program praktik pengalaman lapangan (PPL) merupakan salah satu kegiatan yang wajib dilaksanaan oleh mahasiswa Fakultas Keguruan dan Ilmu Pendidikan, Universitas Islam Sultan Agung Semarang (Unissula) pada semester VII sebagai salah satu syarat untuk mencapai gelar sarjana pendidikan. PPL mencakup latihan mengajar secara terbimbing, terpadu, maupun tugastugas keguruan dan kependidikan lain untuk memenuhi persyaratan profesi kependidikan. Program praktik pengalaman lapangan yang dilaksanakan mahasiswa di sekolah mitra adalah kegiatan kependidikan untuk meningkatkan dan memperdalam keterampilan mahasiswa yang terkait dengan praktik mengajar dan praktik persekolahan (Kusmaryono, dkk., 2016).

Praktek pengalaman lapangan (PPL) adalah praktek kependidikan bagi calon guru. PPL bukan hanya praktek mengajar di sekolah semata. Tetapi mencakup berbagai aktivitas yang berhubungan dengan dunia persekolahan atau keguruan. Dalam kurikulum berbasis kompetensi, PPL merupakan bagian integral dalam pembentukan profesionalisme keguruan. PPL merupakan proses penyatuan wilayah teoritik berbagai mata kuliah metodologi pembelajaran dan manajemen pendidikan.

Secara praktis PPL mencakup dua kegiatan yaitu (1) pembelajaran di kelas sesungguhnya (real teaching/real classroom teaching) yaitu pembelajaran yang dilakukan oleh mahasiswa praktikan di sekolah dalam kelas baik dalam bimbingan (supervied teaching) sampai dapat bertangungjawab penuh (full responsibility teaching) dan (2) Praktek berbagai aktivitas yang berhubungan dengan sekolah (field familiarization) yang dimaksudkan sebagai upaya memperkenalkan mahasiswa praktikan akan kehidupan sekolah (school life).

PPL merupakan salah satu komponen terpenting dalam peningkatan mutu calon pendidik sehingga pelaksanaan program PPL dari waktu ke waktu perlu dievaluasi. Oleh karena itu, peneliti merasa tertarik untuk mengangkat tema ini dalam penelitian dengan judul: "Penerapan pembelajaran berkarakter Islami pada program PPL mahasiswa pendidikan matematika di Universitas Islam Sultan Agung Semarang tahun 2016/2017”.

Pembelajaran matematika bertujuan mengembangkan kemampuan memecahkan masalah, komunikasi matematis, dan menghubungkan ide-ide antar matematika atau matemnatika dengan ilmu lain. Sedangkan efek yang ditimbulkan akbibat belajar matematika adalah sangat dasyat karena sanggup mempengaruhi perilaku yaitu mengembangkan sikap cinta kebenaran, kejujuran, ketelitian, bertindak cermat, tidak ceroboh, tekun dan ulet, serta tidak mudah menyerah, dan tidak putus asa, dan timbul rasa percaya diri yang kuat. Jadi belajar matematika sangat erat kaitannya dengan pembentukan karakter al-akblaqul karimah (Abdussakir, 2007).

Matematika ditinjau dari filosofinya bersumber dari Al Quran (Haryani, 2016). Terbukti bahwa Al-Quran mengandung ayat-ayat yang menuansai berhitung bilangan. Misalnya pada Surat An-nisa ayat 11 dan 12 tentang penekanan pembagian warisan, pada Surat An'Aam ayat 96 perihal peredaran matahari dan bulan dapat membantu manusia dalam perhitungan waktu, dan masih banyak ayat-ayat lainnya.

Beberapa strategi pembelajaran matematika berkarakter Islami dikaitkan dengan penanaman nilai-nilai ajaran Islam dalam pembelajaran matematika sebagaimana disampaikan oleh Yasri (2013), yaitu Selalu menyebut nama Allah, Penggunaan istilah, Ilustrasi visual, Aplikasi atau contoh-contoh, Menyisipkan ayat atau hadits yang relevan, Penelusuran sejarah, Jaringan topic, dan Simbol ayatayat kauniah (ayat-ayat alam semesta)

Strategi ini akan efektif jika kita mengkaji dan menyiasati materi yang kemungkinan bisa dinuansai atau disisipi nilai-nilai ajaran Islam dalam pembelajaran dengan tidak menyimpang dari standar kompetensi atau kompetensi dasar yang dijabarkan dalam uraian materi. Sedangkan, lebih lanjut Abdussakir (2007) menyatakan bahwa:

Strategi implementasi (internalisasi) nilai - nilai Islam yang dapat dilakukan dalam pembelajaran di kelas antara lain melalui metode: (a) Infusi yaitu dalam mengajarkan 
matematika, guru menekankan aspek nilai al-Quran yang ada dalam materi, (b) Analogi yaitu dalam mengajarkan matematika, guru melakukan analogi nilai kebaikan, (c) Narasi yaitu dalam mengajarkan matematika, guru menceritakan kisah-kisah berkaitan dengan matematika dan matematikawan muslim untuk diambil hikmahnya, dan (d) Uswah Hasanah yaitu dalam mengajarkan matematika, guru menunjukkan perilaku yang patut dicontoh terkait matematika misalnya kejujuran, kesungguhan, ketepatan, ketaatan, dan ketelitian.

Untuk dapat melihat keberhasilan proses kegiatan pembelajaran, seluruh faktor-fakor yang berhubungan dengan guru dan siswa harus dapat diperhatikan. Mulai dari perilaku guru dalam mengajar sampai dengan tingkah laku siswa sebagai timbal balik dari hasil sebuah pembelajaran (Karya, W.I., 2015). Aktivitas guru (mahasiswa PPL) yang diamati dalam penelitian ini meliputi: (1) membuka pelajaran, (2) penggunaan media, (3) pendekatan pembelajaran berkarakter Islami, (4) penguasaan materi, (5) kemampuan verbal dan non-verbal, (6) teknik penilaian, (7) penggunaan waktu, (8) menutup pelajaran, dan (9) penyusunan perencanaan pembelajaran (Kusmaryono, dkk, 2016).

Tingkah laku siswa ketika mengikuti proses belajar mengajar merupakan indikasi ada atau tidaknya ketertarikan siswa terhadap pelajaran atau bahkan siswa merasa tidak tertarik dengan pelajaran. Ketertarikan siswa inilah yang merupakan indikasi adanya minat. Menurut Syaiful Bahri Djamarah (2011: 166) Minat adalah kecenderungan yang menetap untuk memperhatikan dan mengenang beberapa aktivitas. Sedangkan menurut Slameto (2010: 180), "minat adalah rasa suka dan rasa ketertarikan pada suatu hal atau aktivitas, tanpa ada yang menyuruh.

Adapun tujuan dari penelitian ini adalah untuk mengetahui tingkat keefektifan dari penerapan pembelajaran berkarakter Islami dalam pelaksanaan PPL, sebagai bekal kompetensi calon guru pada mahasiswa pendidikan matematika Universitas Islam Sultan Agung (Unissula) Semarang. Lebih lanjut dijelaskan bahwa manfaat penelitian ini antara lain (1) memberikan gambaran deskriptif tentang keefektifan pembelajaran berkarakter Islami dalam pembelajaran matematika, (2) memberikan inovasi pembelajaran kepada para guru bahwa pembelajaran berkarakter Islami merupakan salah satu pembelajaran yang efektif dalam meningkatkan prestasi belajar siswa, aktivitas dan minat siswa serta kepercayaan diri siswa dalam belajar, dan (3) pihak sekolah dapat merekomendasikan kepada para guru di sekolah untuk melakukan inovasi pembelajaran melalui pembelajaran berkarakter islami.

\section{METODE PENELITIAN}

Penelitian ini menggunakan metode penelitian kombinasi kuantitatif dan kualitatif dengan pendekatan concurrent embedded dimana metode kuantitatif sebagai metode primer (Sugiyono, 2011). Pendekatan kuantitatif digunakan untuk membandingkan hasil belajar siswa antara yang mendapat pembelajaran matematika berkarakter Islami (sebagai kelompok eksperimen) dan siswa yang mendapatkan pembelajaran matematika tanpa berkarakter Islami (sebagai kelompok kontrol). Pada pendekatan kualitatif digunakan untuk mendeskripsikan tingkat aktivitas pembelajaran mahasiswa PPL, minat siswa, dan tanggapan guru pamong di sekolah mitra tempat PPL terhadap penerapan pembelajaran matematika berkarakter Islami. Desain penelitian gabungan ini digambarkan sebagai berikut: 


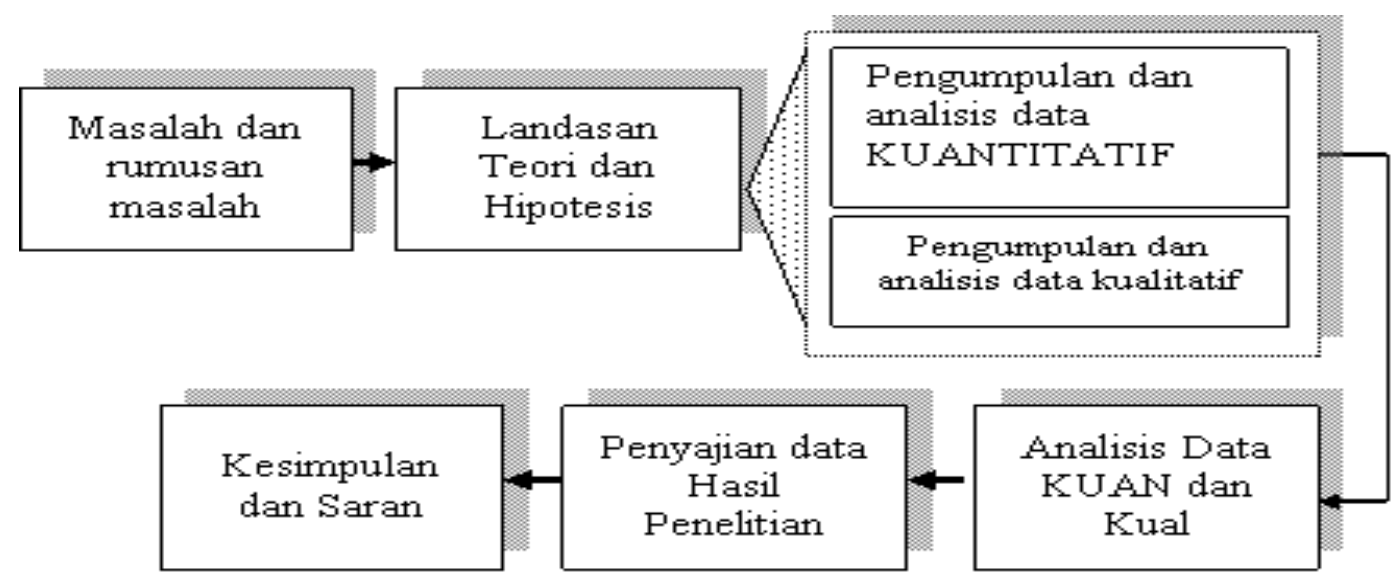

Gambar 1. Metode penelitian kombinasi concurrent embedded (Sugiyono, 2011)

Populasi penelitian ini adalah seluruh mahasiswa peserta program PPL program studi pendidikan matematika Unissula Semarang. Jumlah peserta PPL sebanyak 87 mahasiswa yang tersebar pada 15 sekolah mitra seperti yang disajikan dalam Tabel 1 di bawah ini.

Tabel 1. Daftar Sekolah Mitra dan Mahasiswa PPL

\begin{tabular}{clc}
\hline No. & \multicolumn{1}{c}{ Sekolah Mitra Tempat PPL } & $\begin{array}{c}\text { Jumlah } \\
\text { Mahasiswa }\end{array}$ \\
\hline 1 & SMP Negeri 18 Semarang & 6 \\
\hline 2 & SMP Negeri 20 Semarang & 6 \\
\hline 3 & SMP Negeri 27 Semarang & 6 \\
\hline 4 & SMP Negeri 32 Semarang & 6 \\
\hline 5 & SMP Negeri 39 Semarang & 6 \\
\hline 6 & MTs Negeri 2 Semarang & 6 \\
\hline 7 & SMP Islam Sultan Agung 1 Semarang & 6 \\
\hline 8 & SMA Negeri 2 Semarang & 6 \\
\hline 9 & SMA Negeri 6 Semarang & 6 \\
\hline 10 & SMA Negeri 10 Semarang & 6 \\
\hline 11 & SMA Negeri 14 Semarang & 6 \\
\hline 12 & MA Negeri 2 Semarang & 6 \\
\hline 13 & SMA Muhammadiyah 1 Semarang & 6 \\
\hline 14 & SMA Islam Sultan Agung 1 Semarang & 3 \\
\hline 15 & SMK Asodiqiyah Semarang & $\mathbf{8 7}$ \\
\hline
\end{tabular}

Pengambilan sampel dalam penelitian ini diilakukan secara sampling purposive, sehingga semua sekolah terwakili. Akhirnya diperoleh sampel penelitian yang terdiri dari kelompok eksperimen sebanyak 31 mahasiswa PPL dan kelompok kontrol sebanyak 31 mahasiswa PPL. Kelompok eksperimen adalah mahasiswa PPL yang melaksanakan pembelajaran matematika berkarakter Islami dan kelompok kontrol adalah mahasiswa yang melaksanakan pembelajaran matematika tanpa bermuatan karakter Islami. Metode pengumpulan data penelitian meliputi: 1) Dokumentasi, 2) Observasi, 3) Angket, dan 4) Wawancara. 


\section{HASIL PENELITIAN DAN PEMBAHASAN}

Hasil pengamatan aktivitas pembelajaran dari mahasiswa PPL setelah direkap, disajikan dalam tabel pencapaian indicator aktivitas pembelajaran matematika berkarakter Islami yang dilakukan oleh mahasiswa PPL dalam kelompok eksperimen (E) sebagai berikut.

Tabel 2. Pencapaian Indikator Pengamatan Aktivitas Mahasiswa PPL (E)

\begin{tabular}{clcccc}
\hline No & Aktivitas yang diamati & $\begin{array}{c}\text { Skor } \\
\text { Ideal }\end{array}$ & $\begin{array}{c}\text { Skor } \\
\text { Ketercapaian }\end{array}$ & $\begin{array}{c}\text { Prosentase } \\
\%\end{array}$ & Keterangan \\
\hline 1 & Membuka pelajaran & 4,00 & 3,31 & 82,85 & Tinggi \\
\hline 2 & Penggunaan media & 4,00 & 2,96 & 74,00 & Sedang \\
\hline 3 & $\begin{array}{l}\text { Pendekatan } \\
\text { pembelajaran } \\
\text { berkarakter islami }\end{array}$ & 4,00 & 3,18 & 79,6 & Tinggi \\
\hline 4 & Penguasaaan materi & 4,00 & 3,14 & 78,4 & Tinggi \\
\hline 5 & $\begin{array}{l}\text { Kemampuan verbal } \\
\text { dan non verbal }\end{array}$ & 4,00 & 3,20 & 80,0 & Tinggi \\
\hline 6 & Teknik Penilaian & 4,00 & 3,06 & 76,5 & Tinggi \\
\hline 7 & Penggunaan waktu & 4,00 & 2,74 & 68,50 & Sedang \\
\hline 8 & Menutup pelajaran & 4,00 & 3,77 & 94,2 & Tinggi \\
\hline 9 & $\begin{array}{l}\text { Perencanaan } \\
\text { pembelajaran (RPP) }\end{array}$ & 4,00 & 3,85 & 96,25 & Tinggi \\
\hline & Rata-rata skor & --- & 3,23 & 80,91 & Tinggi \\
\hline
\end{tabular}

Hasil mean pencapaian indikator aktivitas mahasiswa PPL adalah 80,91\% artinya aktivitas pembelajaran matematika berkarakter Islami yang dilakukan oleh mahasiswa PPL sebagai kelompok eksperimen termasuk katogori tinggi atau baik.

Sedangkan melalui cara pengamatan yang sama diperoleh data pencapaian indikator aktivitas pembelajaran matematika tanpa bermuatan karakter Islami yang dilakukan oleh mahasiswa PPL sebagai kelompok kontrol $(\mathrm{K})$ yaitu mean pencapaian indikator aktivitas pembelajaran mahasiswa PPL adalah 70,29\% artinya aktivitas pembelajaran matematika tanpa bermuatan karakter Islami yang dilakukan oleh PPL termasuk katogori cukup tinggi. Pencapaian indikator aktivitas pembelajaran ini mewakili pencapaian kompetensi professional dan pedagogik dari mahasiswa PPL, sehingga dengan kata lain dapat dikatakan bahwa kompetensi profesional dan pedagogik dari mahasiswa peserta PPL mencapai kategori baik.

Berdasarkan data angket minat belajar dengan 4 indikator yang dijabarkan dalam 15 item pernyataan diperoleh data berikut. 
Tabel 3. Pencapaian indikator minat belajar siswa

\begin{tabular}{clcccc}
\hline No & Indikator Minat & $\begin{array}{c}\text { Skor } \\
\text { Maks }\end{array}$ & $\begin{array}{c}\text { Skor } \\
\text { Ketercapaian }\end{array}$ & $\begin{array}{c}\text { Persen } \\
\%\end{array}$ & Keterangan \\
\hline 1 & Perasaan Senang & 4,00 & 3,00 & 75,00 & Sedang / cukup \\
\hline 2 & $\begin{array}{l}\text { Perhatian dalam } \\
\text { Belajar }\end{array}$ & 4,00 & 3,15 & 78,75 & Tinggi \\
\hline 3 & $\begin{array}{l}\text { Bahan Pelajaran dan } \\
\text { Sikap Guru yang } \\
\text { menarik }\end{array}$ & 4,00 & 3,30 & 82,50 & Tinggi \\
\hline 4 & $\begin{array}{l}\text { Manfaat dan Fungsi } \\
\text { Mata Pelajaran }\end{array}$ & 4,00 & 2,65 & 66,25 & Sedang / cukup \\
\hline \multicolumn{1}{c}{ Rata-rata } & --- & 3,03 & 75,63 & Tinggi \\
\hline
\end{tabular}

Pencapaian indikator minat siswa mengikuti pembelajaran matematika pada kelompok eksperimen mencapai rata-rata sebesar $75,63 \%$ artinya minat siswa terhadap pembelajaran matematika berkarakter Islami yang dilakukan oleh mahasiswa PPL termasuk katogori tinggi.

Hasil belajar pada ranah kognitif yang datanya diambil melalui metode tes (pencils and paper test) diakhir pertemuan diperoleh data pada kelompok eksperimen (E) dapat dilihat pada tabel di bawah ini.

Tabel 4. Deskripsi statistik hasil belajar siswa (E)

\begin{tabular}{lr}
\hline \multicolumn{2}{c}{ Nilai E } \\
\hline Valid & 31 \\
\hline Missing & 0 \\
\hline Mean & 76.52 \\
\hline Median & 76.00 \\
\hline Mode & 77 \\
\hline Std. Deviation & 5.065 \\
\hline Variance & 25.658 \\
\hline Range & 20 \\
\hline Minimum & 69 \\
\hline Maximum & 89 \\
\hline c...m & 2270
\end{tabular}

Dari data Tabel 4, dapat dijelaskan bahwa ilaii rata-rata hasil belajar siswa pada pembelajaran matematika berkarakter Islami oleh mahasiswa PPL pada kelas eksperimen (E) secara klasikal mencapai sebesar 76,52 dengan klasifikasi nilai baik.

Selanjutnya nilai rata-rata hasil belajar siswa pada kelompok kontrol $(K)$ dapat dilihat pada tabel di bawah ini.

Tabel 5. Deskripsi statistik hasil belajar siswa (K)

\begin{tabular}{|c|c|c|}
\hline \multicolumn{3}{|c|}{ Statistics } \\
\hline \multicolumn{3}{|c|}{ Nilai K } \\
\hline \multirow[t]{2}{*}{$\mathrm{N}$} & Valid & 31 \\
\hline & Missing & 0 \\
\hline \multicolumn{2}{|c|}{ Mean } & 70.29 \\
\hline \multicolumn{2}{|c|}{ Median } & 70.00 \\
\hline \multicolumn{2}{|c|}{ Mode } & $68^{a}$ \\
\hline \multicolumn{2}{|c|}{ Std. Deviation } & 5.430 \\
\hline \multicolumn{2}{|c|}{ Variance } & 29.480 \\
\hline \multicolumn{2}{|c|}{ Range } & 24 \\
\hline \multicolumn{2}{|c|}{ Minimum } & 60 \\
\hline \multicolumn{2}{|c|}{ Maximum } & 84 \\
\hline \multicolumn{2}{|c|}{ Sum } & 2179 \\
\hline
\end{tabular}


Meninjau Tabel 5 di atas menunjukkan bahwa mean kelompok control sebesar 70,29. Dari data tersebut dapat disimpulkan bahwa rata-rata hasil belajar siswa pada pembelajaran matematika tanpa bermuatan karakter Islami oleh mahasiswa PPL pada kelas kontrol $(\mathrm{K})$ secara klasikal nilai rata-rata hasil belajarnya sebesar 70,29 dengan klasifikasi nilai cukup baik atau sedang.

Untuk menguji ada tidaknya pengaruh variable aktivitas mahasiswa PPL $\left(\mathrm{X}_{1}\right)$ dan minat belajar siswa $\left(\mathrm{X}_{2}\right)$ terhadap hasil belajar siswa pada kelompok eksperimen, dilakukan analisis data dengan SPSS versi 11.5, dengan hasil analisis data sebagai berikut.

Tabel 6. Hasil analisis regresi berganda Coefficients

\begin{tabular}{|c|c|c|c|c|c|c|c|c|c|}
\hline \multirow[b]{2}{*}{ Model } & \multicolumn{2}{|c|}{$\begin{array}{c}\text { Unstandardized } \\
\text { Coefficients }\end{array}$} & \multirow{2}{*}{$\begin{array}{c}\begin{array}{c}\text { Standardized } \\
\text { Coefficients }\end{array} \\
\text { Beta }\end{array}$} & \multirow[b]{2}{*}{$t$} & \multirow[b]{2}{*}{ Sig. } & \multicolumn{2}{|c|}{$\begin{array}{c}\text { 95\% Confidence } \\
\text { Interval }\end{array}$} & \multicolumn{2}{|c|}{ Collinearity Statistic } \\
\hline & $B$ & $\begin{array}{l}\text { Std. } \\
\text { Error }\end{array}$ & & & & $\begin{array}{l}\text { Lower } \\
\text { Bour }\end{array}$ & $\begin{array}{l}\text { Upper } \\
\text { Bour }\end{array}$ & Tolerance & VIF \\
\hline 1 & 36,907 & 11,529 & & 3,201 & ,003 & 2,343 & 59,627 & & \\
\hline (Constant) & ,200 &, 141 & ,210 & 1,422 & ,013 & ,881 & ,489 & ,999 & 1,001 \\
\hline $\begin{array}{l}\text { NILAIX! } \\
\text { NILAIX2 }\end{array}$ & ,634 & , 165 & ,568 & 3,852 & ,001 &, 971 & ,971 & ,999 & 1,001 \\
\hline
\end{tabular}

a. Denendent Variable NILAIY

Berdasarkan Tabel 6 Coefficients di atas dapat ditentukan persamaan regresi ganda, yaitu $\hat{Y}=$ $36,907+0,200 X_{1}+0,634 X_{2}$, dimana $\mathrm{Y}$ adalah hasil belajar, $\mathrm{X}_{1}$ (variabel aktivitas PPL) dan $\mathrm{X}_{2}$ (variabel minat). Harga 36,907 merupakan nilai konstanta yang menunjukkan bahwa jika seseorang siswa nilai aktivitas dan motivasinya sama dengan 0 (nol) maka hasil belajar yang diperoleh sebesar 36,907. Harga 0,200 merupakan koefisien regresi dari $\mathrm{X}_{1}$ (variabel aktivitas PPL) yang menunjukkan bahwa setiap kenaikan satu satuan dari $\mathrm{X}_{1}$ dan harga $\mathrm{X}_{2}$ kontan maka hasil belajar siswa akan mengalami kenaikan skor sebesar 0,200. Sedangkan harga 0,634 merupakan koefisien regresi dari $\mathrm{X}_{2}$ (variabel minat) yang menunjukkan bahwa setiap kenaikan satu satuan dari $\mathrm{X}_{2}$ dan harga $\mathrm{X}_{1}$ kontan maka hasil belajar siswa akan mengalami kenaikan skor sebesar 0,634.

Selanjutnya sebelum menentukan seberapa besar pengaruh variabel independent (aktivitas dan motivasi) terhadap variabel dependent (hasil belajar), terlebih dahulu dilakukan uji keberartian dan kelinearan persamaan regresi. Hasil pengujian hipotesis keberartian analisis menggunakan SPSS versi 11.5 diperoleh bahwa nilai $\mathrm{F}_{\text {hitung }}=9,961$ lebih besar daripada $\mathrm{F}_{\text {tabel }}=2,38$, dengan probabilitas (Sig.) sebesar $0,001=0,1 \%$ kurang dari $5 \%$, maka $\mathrm{H}_{0}$ ditolak. Kesimpulannya koefisien regresi berarti dengan kata lain ada hubungan yang berarti antara aktivitas pembelajaran mahasiswa PPL dan minat siswa terhadap hasil belajar.

Memperhatikan tabel 6 dapat dikatakan bahwa koefisien $\beta$ untuk $\mathrm{X}_{1}$ dan $\mathrm{X}_{2}$ adalah positif yakni masing-masing 0,210 dan 0,568 maka dikatakan hubungan tersebut positif. Positif berarti aktivitas dan minat mempunyai hubungan linier terhadap hasil belajar. Tabel 6 di atas juga menunjukkanbahwa hubungan $\mathrm{X}_{1}$ dan $\mathrm{X}_{2}$ terhadap $\mathrm{Y}$ adalah linier berarti dan besarnya koefisien korelasi adalah 0,210 dan 0,568 .

Untuk melihat besar pengaruh atau kontribusi aktivitas $\left(\mathrm{X}_{1}\right)$ dan minat $\left(\mathrm{X}_{2}\right)$ terhadap hasil belajar $\left(\mathrm{Y}_{1}\right)$ dapat dilihat nilai $\mathrm{R}$ square (koefisien determinasi) pada tabel 7 berikut.

Tabel 7. Kontribusi aktivitas dan minat terhadap hasil belajar Model Summary b

\begin{tabular}{c|cccc}
\hline Model & $R$ & $R$ Square & $\begin{array}{c}\text { Adjusted } R \\
\text { Square }\end{array}$ & $\begin{array}{c}\text { Std. Error of } \\
\text { the Estimate }\end{array}$ \\
\hline 1 & $0,645^{\text {a }}$ &, 416 &, 374 & 4,008 \\
\hline
\end{tabular}

a. Predictors : (Constant), VARX2, VARX1

b. Dependent Variable : NILAIY

Dari data di atas diperoleh nilai $R$ square (indeks determinasi sebesar 0,416 $=41,6 \%$. Ini berarti 41,6\% variasi yang terjadi di dalam $\mathrm{Y}$ dapat dijelaskan oleh $\mathrm{X}_{1}$ dan $\mathrm{X}_{2}$ melalui model 
regresi $\hat{Y}=33,906+0,200 \mathrm{X}_{1}+0,634 \mathrm{X}_{2}$, sedangkan $58,4 \%$ nya dipengaruhi oleh variabel lain. Dengan kata lain kontribusi aktivitas mahasiswa PPL dan minat siswa terhadap hasil belajar matematika sebesar 0,416 $=41,6 \%$, berarti aktivitas mahasiswa PPL dan minat siswa mempengaruhi hasil belajar sebesar 41,6\%, sedangkan ada variabel lain yang berpengaruh sebesar $58,4 \%$.

Pengujian ini dilakukan untuk mencari jawaban dari rumusan masalah "Apakah terdapat perbedaan hasil belajar antara siswa pada pembelajaran matematika berkarakter islami dan pembelajaran matematika tanpa bermuatan karakter islami oleh mahasiswa PPL?” Berdasar analisis data menggunakan program SPSS versi 11.5 diperoleh hasil pada Tabel 8 berikut

Tabel 8. Deskripsi data hasil belajar siswa

\begin{tabular}{lrrr}
\hline \multicolumn{3}{c}{ Statistics } & \\
\hline & Nilai K & Nilai E \\
\cline { 2 - 5 } & Valid & 31 & 31 \\
\cline { 2 - 5 } Missing & 0 & & 0 \\
\hline Mean & 70.29 & 76.52 & \\
\hline Median & 70.00 & 76.00 & \\
\hline Mode & $68^{\mathrm{a}}$ & & 77 \\
\hline Std. Deviation & 5.430 & 5.065 & \\
\hline Variance & 29.480 & 25.658 & \\
\hline Range & 24 & & 20 \\
\hline Minimum & 60 & & 69 \\
\hline Maximum & 84 & & 89 \\
\hline Sum & 2179 & & 2372 \\
\hline
\end{tabular}

Berdasar Tabel 8 pada deskripsi data hasil belajar siswa kelompok eksperimen (E) dan kontrol $(\mathrm{K})$ terlihat mean (nilai rata-rata) yakni mean $(\mathrm{E})=76,52$ dan mean $(\mathrm{K})=70,29$. Juga dapat dilihat perolehaan nilai minimum kelompok (E) sebesar 69 dan kelompok $(\mathrm{K})$ sebesar 60, nilai maksimum yang diperoleh kelompok (E) mencapai 89 dan kelompok (K) mencapai 84.

Selanjutnya untuk mengetahui adanya perbedaan rata-rata nilai hasil belajar siswa antara kelompok (E) dan kelompok (K) dilakukan pengujian melalui statistik uji t (Independent Samples Test). Hasil pengujian statistik disajikan dalam Tabel 9 di bawah ini.

Tabel 9. Uji t (Independent Samples Test)

\begin{tabular}{|c|c|c|c|c|c|c|c|c|c|}
\hline & & \multirow{2}{*}{\multicolumn{2}{|c|}{$\begin{array}{l}\text { Levene's Test for } \\
\text { Equality of } \\
\text { Variances }\end{array}$}} & \multicolumn{6}{|c|}{ t-test for Equality of Means } \\
\hline & & & & \multirow[t]{2}{*}{$\mathrm{t}$} & \multirow[t]{2}{*}{$\mathrm{df}$} & \multirow[t]{2}{*}{$\begin{array}{l}\text { Sig. (2- } \\
\text { tailed) }\end{array}$} & \multirow[t]{2}{*}{$\begin{array}{c}\text { Mean } \\
\text { Difference }\end{array}$} & \multicolumn{2}{|c|}{$\begin{array}{l}95 \% \text { Confidence Interva } \\
\text { of the Difference }\end{array}$} \\
\hline & & $\mathrm{F}$ & Sig. & & & & & Lower & Uppe \\
\hline \multirow[b]{2}{*}{ Nilai } & $\begin{array}{l}\text { Equal } \\
\text { variances }\end{array}$ & ,344 &, 560 & 5,505 & 53 & ,000 & 1,522 & 5,325 & 11,428 \\
\hline & $\begin{array}{l}\text { assumed } \\
\text { Equal } \\
\text { variances } \\
\text { not } \\
\text { assumed }\end{array}$ & & & & 47,865 & ,000 & 1,535 & 5,290 & 11,462 \\
\hline
\end{tabular}

Dari output bagian independent t-test, nampak bahwa untuk Levenes Test pada baris pertama (Equal variances assumed) nilai $\mathrm{F}=0,344$ dengan Sig. $=0,560$ dengan tingkat kepercayaan $95 \%$. Hal ini berarti Sig. $=0,560 \geq 0,05$, sehingga Ho diterima. Maka kesimpulannya varians 
kelompok eksperimen (E) dan kelompok kontrol $(\mathrm{K})$ adalah sama atau identik. Sedangkan berdasar perbandingan nilai t_tabel dengan $t \_h i t u n g$ diperoleh t_tabel $=1,71$ dan t_hitung $=$ 5,505. Ini berarti $\mathrm{t} \_$tabel $\leq \mathrm{t} \_$hitung sehingga Ho ditolak. Hal ini juga didukung oleh nilai Sig. $=0,00$ dengan tingkat kepercayaan 95\%, berarti Sig. $=0,00<0,05$, sehingga Ho ditolak. Karena hasil keputusan Ho ditolak, maka kesimpulannya adalah rata-rata nilai hasil belajar siswa dalam kelompok eksperimen (E) berbeda secara signifikan dengan kelompok kontrol (K). dengan kata lain bahwa rata-rata nilai hasil belajar siswa dalam pembelajaran matematika berkarakter Islami lebih baik daripada rata-rata nilai hasil belajar pembelajaran matematika tanpa bermuatan berkarakter Islami.

Guna mendukung hasil penelitian kuantitatif, berikut disajikan cuplikan wawancara untuk mengetahui respon guru pamong dan siswa terhadap pelaksanaan pembelajaran matematika berkarakter islami yang dilakukan mahasiswa PPL.

Tabel. 10 Wawancara terhadap Guru Pamong di sekolah mitra PPL

\begin{tabular}{|c|c|c|}
\hline Peneliti & : & $\begin{array}{l}\text { Apakah mahasiswa PPL ada melaksanakan model pembelajaran } \\
\text { berkarakter islami? }\end{array}$ \\
\hline Guru & : & $\begin{array}{l}\text { Alhamdulillah,.. ada mahasiswa PPL yang saya bimbing } \\
\text { melaksanakan pembelajaran matematika berkarakter islami. }\end{array}$ \\
\hline Peneliti & $:$ & $\begin{array}{l}\text { Menurut Ibu, apakah model pembelajaran tersebut cocok untuk } \\
\text { materi yang disampaikan? }\end{array}$ \\
\hline Guru & $:$ & Sangat cocok. \\
\hline Peneliti & : & $\begin{array}{l}\text { Bagaimana kesan Ibu terhadap model pembelajaran matematika } \\
\text { berkarakter Islami? }\end{array}$ \\
\hline Guru & : & $\begin{array}{l}\text { Cukup menarik, model pembelajaran ini tentunya merupakan hal } \\
\text { yang baru. }\end{array}$ \\
\hline Peneliti & $:$ & Dapat dijelaskan lebih mendalam Ibu, mengapa menarik? \\
\hline Guru & $:$ & $\begin{array}{l}\text { Ya...karena dengan menyisipkan ayat-ayat Al Quran akan } \\
\text { menambah wawasan keislaman dan keimanan siswa terhadap Allah } \\
\text { Tuhan YME. }\end{array}$ \\
\hline Peneliti & : & $\begin{array}{l}\text { Apakah tidak mengganggu jika ada siswa yang beragama selain } \\
\text { Islam? }\end{array}$ \\
\hline Guru & $:$ & $\begin{array}{l}\text { Saya rasa tidak mengganggu, karena pembelajaran ini tidak } \\
\text { bermaksud memaksa seseorang untuk memeluk agama tertentu. } \\
\text { Tetapi lebih menekankan pendidikan karakter bahwa setiap } \\
\text { manusia wajib bertaqwa terhadap Tuhan YME dan mensyukuri } \\
\text { karuniannya. }\end{array}$ \\
\hline & & Tabel 11. Wawancara terhadap siswa di sekolah mitra \\
\hline Peneliti & : & $\begin{array}{l}\text { Apakah mahasiswa PPL ada melaksanakan model pembelajaran } \\
\text { berkarakter islami? }\end{array}$ \\
\hline Siswa & : & $\begin{array}{l}\text { Iya ada. mahasiswa PPL melaksanakan pembelajaran matematika } \\
\text { berkarakter Islami. }\end{array}$ \\
\hline Peneliti & $:$ & $\begin{array}{l}\text { Menurut Ibu, apakah model pembelajaran tersebut cocok untuk } \\
\text { materi yang disampaikan? }\end{array}$ \\
\hline Siswa & $:$ & Sangat bagus, cocok \\
\hline Peneliti & $:$ & $\begin{array}{l}\text { Bagaimana kesan Anda terhadap penerapan model pembelajaran } \\
\text { matematika berkarakter Islami? }\end{array}$ \\
\hline Siswa & $:$ & $\begin{array}{l}\text { Cukup senang dan tidak membosankan, model pembelajaran ini } \\
\text { tentunya berbeda dari biasanya. }\end{array}$ \\
\hline Peneliti & : & Apa manfaat yang Anda peroleh? \\
\hline
\end{tabular}




\begin{tabular}{lll}
\hline Siswa & $:$ & $\begin{array}{l}\text { Senang aja, belajar lebih semangat, terus menambah wawasan } \\
\text { keislaman dan keimanan siswa terhadap Tuhan YME. }\end{array}$ \\
\hline Peneliti $:$ & $\begin{array}{l}\text { Apakah tidak mengganggu jika ada siswa yang beragama selain } \\
\text { Islam? }\end{array}$ \\
\hline Siswa $: \quad \begin{array}{l}\text { Tidak mengganggu, karena di sekolah ini setiap pagi juga membaca } \\
\text { Asmaul Husna dan berdoa juga mmnurut agama Islam dan yang } \\
\text { non-Islam ya berdoa sesuai agamanya sendiri }\end{array}$ \\
\hline
\end{tabular}

Berdasarkan Tabel 10 dan Tabel 11, terhadap guru pamong dan siswa dapat dideskripsikan bahwa guru pamong sangat mengapresiasi keberanian mahasiswa PPL yang menerapkan pembelajaran matematika berkarakter Islami. Guru pamong di sekolah mitra juga menyatakan bahwa pembelajaran berkarakter Islami secara tidak langsung merupakan proses pembentukan karakter melalui pelajaran matematika. Sementara itu, perwakilan siswa menyatakan bahwa ide penerapan pembelajaran berkarakter Islami sangat menarik minat siswa untuk belajar tentang nilainilai Islam yang terkandung dalam matematika.

\section{PENUTUP}

\section{Simpulan}

Berdasarkan hasil penelitian dan pembahasan dapat disimpulkan bahwa penerapan pembelajaran berkarakter Islami dalam pelaksanaan PPL, efektif sebagai bekal kompetensi calon guru bagi mahasiswa pendidikan matematika di Universitas Islam Sultan Agung Semarang tahun 2016/2017. Keefektifan penelitian ini terpenuhi oleh unsur sebagai berikut: (1) Kompetensi pedagogik dan profesional mahasiswa pendidikan matematika dalam program PPL di sekolah mitra mencapai kategori baik yaitu rata-rata skor hasil pengamatan sebesar 78,39, (2) Terdapat pengaruh aktivitas pembelajaran mahasiswa PPL dan minat siswa terhadap hasil belajar matematika dalam pembelajaran berkarakter Islami dengan persamaan regresi ganda $\hat{Y}=36,907+0,200 X_{1}+0,634 X_{2}$, yang bersifat linier. Besarnya kontribusi aktivitas dan minat siswa terhadap hasil belajar ditunjukkan dari nilai $R$ square (indeks determinasi) sebesar 0,416 atau 41,6\%, artinya aktivitas mahasiswa PPL dan minat siswa mempengaruhi hasil belajar sebesar 41,6\%, sedangkan ada variabel lain yang berpengaruh sebesar 58,4\%, dan (3) Hasil belajar matematika siswa melalui pembelajaran berkarakter Islami mencapai 76,52 yang berarti lebih baik daripada hasil belajar siswa dalam pembelajaran matematika tidak berkarakter Islami hanya mencapai 70,29. Aktivitas pelaksanaan pembelajaran matematika berkarakter Islami yang dilaksanakan mahasiswa PPL sudah memenuhi standard yang ditetapkan oleh program studi. Sedangkan minat siswa terhadap pembelajaran matematika berkarakter Islami juga tinggi.

\section{UCAPAN TERIMA KASIH}

Atas selesainya penelitian ini, tidak lupa penulis mengucapkan terima kasih kepada seluruh Kepala SMP dan Kepala SMA di kota Semarang beserta bapak/ibu Guru di sekolah mitra yang telah bersedia bekerja sama dalam program PPL dengan FKIP Universitas Islam Sultan Agung Semarang. Semoga ke depan kerjasama ini terus terjalin dengan baik sehingga memberikan sumbangan bagi perkembangan pendidikan di Indonesia.

\section{DAFTAR PUSTAKA}

Abdussakir. (2007). Ketika Kyai Mengajar Matematika. Malang: UIN-Maliki Press.

Abdussakir. (2009). Matematika 1: Kajian Integratif Matematika dan Al-Qur'an. Malang: UIN-Maliki Press.

Hariyani, M. (2013). Strategi Pembelajaran Matematika Madrasah Ibtidaiyah Berintegrasi Nilai-nilai Islam. Jurnal Menara, 12 (2), 150-155. Tersedia online: ejournal.uinsuska.ac.id/index.php/Menara/article/download/418/399 
Karya, I.W., (2015). Menumbuhkembangkan Minat Belajar Siswa-siswi Tingkat Dasar dan Menengah di Pasraman Kilat Batola. Jurnal Satya Dharma, 2(2), p.94. Tersedia online: http:/ /jurnal.stahntp.ac.id/index.php/Satya-Dharma/article/view/94

Kusmaryono, I., dkk. 2015. Pedoman PPL FKIP Unissula 2016. Semarang: Unissula Press.

Slameto, (2010). Belajar Dan Faktor-Faktor Yang Mmpengarubinnya. Jakarta: PT. Rineka Cipta.

Sugiyono.2011. Metode Penelitian Kombinasi (Mixed Methods). Bandung: Alfabeta

Syaiful Bahri Djamarah. (2011). Psikologi Belajar. Jakarta: Rineka Cipta.

Yasri. (2013). Strategi Pembelajaran Matematika yang Bernuansa Islami. [Online]. (Tersedia: http://bdkpadang.kemenag.go.id) 